\title{
Research Article: Extent of adoption of ANGRAU technologies of Paddy crop in Kadapa district of Andhra Pradesh
}

\section{N. Krishna Priya and B. Padmodaya}

Article Chronicle: Received : 14.05.2020;

Revised:

12.06.2020;

Accepted :

14.07.2020

KeY Words:

Technologies, Adoption, Varieties

Author for correspondence :

\section{N. Krishna Priya}

Krishi Vigyan Kendra, Utukur, Kadapa (A.P.) India

Email: Priyarambabu143

(a) gmail.com

See end of the article for authors' affiliations
SUMMARY : The study was conducted to analyse the extent of adoption of ANGRAU technologies of paddy crop in Kadapa district of Andhra Pradesh. Mainly six mandals were selected based on the paddy growing areas. From six mandals 12 villages were selected and from each village 5 farmers were selected randomly. Total sample size for the study was 60 farmers. The results revealed that the varieties adopted by most of the paddy growing farmers (41.67\%) adopted NDLR-7 and majority ( $83.33 \%)$ of the farmers discontinued variety BPT-5204. The recommendations with regard to crop production technologies applying well decomposed FYM/Compost @ $200 \mathrm{~kg} / 5$ cents nursery there is 100 per cent adoption by the farmers. With respect to weed management aspects application of pretilachlor @ $500 \mathrm{ml} /$ acre or oxadiargyl@35-40g/acre within 3 to 5 days of transplanting recorded 81.67 per cent adoption by the farmers. In case of plant protection measures for BPH pest, spray acephate @1.g or monocrotophos @ $2.2 \mathrm{ml}$ or ethofenprox@2ml or thiamethoxam@0.25g or buprofezin $1.6 \mathrm{ml}$ or pymetrozine $0.6 \mathrm{~g}$ or imidacloprid+ethiprole $0.2 \mathrm{~g}$ or dinotefuron $0.4 \mathrm{~g} / \mathrm{l}$ there is 80 per cent adoption by the farmers.

How to cite this article : Priya, N. Krishna and Padmodaya, B. (2020). Extent of adoption of ANGRAU technologies of Paddy crop in Kadapa district of Andhra Pradesh. Agric. Update, 15(3): 205-210; DOI : 10.15740/ HAS/AU/15.3/205-210. Copyright@ 2020: Hind Agri-Horticultural Society. 